MacLennan, S. et al. (2017) A core outcome set for localised prostate cancer effectiveness trials. BJU International, 120(5B), E64-E79. (doi:10.1111/bju.13854)

There may be differences between this version and the published version. You are advised to consult the publisher's version if you wish to cite from it.

This is the peer-reviewed version of the following article: MacLennan, S. et al. (2017) A core outcome set for localised prostate cancer effectiveness trials. BJU International, 120(5B), E64-E79, which has been published in final form at 10.1111/bju.13854. This article may be used for non-commercial purposes in accordance with Wiley Terms and Conditions for Self-Archiving.

http://eprints.gla.ac.uk/139403/

Deposited on: 11 April 2017

Enlighten - Research publications by members of the University of Glasgow http://eprints.gla.ac.uk 
DR. STEVEN MACLENNAN (Orcid ID : 0000-0002-2691-8421)

Received Date : 01-Feb-2017

Revised Date : 08-Mar-2017

Accepted Date : 20-Mar-2017

Article type : Original Article

\section{A core outcome set for localised prostate cancer effectiveness trials}

Steven MacLennan ${ }^{1 *}$, Paula R Williamson ${ }^{2}$, Hanneke Bekema ${ }^{3}$, Marion Campbell ${ }^{4}$, Craig Ramsay ${ }^{4}$, James N'Dow ${ }^{1,5}$, Sara MacLennan ${ }^{1}$, Luke Vale ${ }^{6}$, Philipp Dahm ${ }^{14}$, Nicolas Mottet ${ }^{23}$ and Thomas Lam ${ }^{1,5}$ on behalf of the COMPACTERS study group: Paul Abel ${ }^{7}$, Hashim U. Ahmed ${ }^{8}$, Gary Akehurst ${ }^{9}$, Robert Almquist ${ }^{9}$, Karl Beck $^{9}$, David Budd ${ }^{9}$, Steven Canfield ${ }^{10}$, James Catto ${ }^{11}$, Philip Cornford ${ }^{12}$, William Cross $^{13}$, Alexander Ewen ${ }^{9}$, Judith Grant ${ }^{15}$, Rakesh Heer ${ }^{16}$, David Hurst ${ }^{9}$, Rob Jones ${ }^{17}$, Roger Kockelbergh $^{18}$, Andrew Mackie ${ }^{9}$, Graham MacDonald ${ }^{15}$, Alan McNeill ${ }^{19}$, Malcolm Mason ${ }^{20}$, Sam McClinton $^{5}$, Duncan McLaren ${ }^{21}$, Hugh Mostafid ${ }^{22}$, Ian Pearce ${ }^{24}$, Linda Pennet ${ }^{5}$, Justine Royle ${ }^{5}$, Hans Schreuder ${ }^{9}$, Grant D. Stewart ${ }^{25}$, Henk van der Poel ${ }^{26}$, Kevin Wardlaw $^{5}$, Thomas Wiegel ${ }^{27}$,

${ }^{*}$ Corresponding author: steven.maclennan@abdn.ac.uk

1 Academic Urology Unit, University of Aberdeen, Aberdeen, UK

2 Department of Biostatistics, University of Liverpool, Crown Street, Liverpool, UK 
3 Department of Anaesthesiology, University of Groningen, University Medical Centre Groningen, Groningen, The Netherlands

4 Health Services Research Unit, University of Aberdeen, Aberdeen, UK

5 Department of Urology, Aberdeen Royal Infirmary, Aberdeen, UK

6 Health Economics Group, Institute of Health and Society, University of Newcastle, Newcastle, UK

7 Faculty of Medicine, Department of Surgery \& Cancer, Imperial College London, London, UK

8 Division of Surgery and Interventional Science, University College London, London, UK; Department of Urology, University College London Hospitals NHS Foundation Trust, London, UK

9 Patient representative

10 Division of Urology, University of Texas Medical School at Houston, Houston, Texas, USA

11 University of Sheffield Academic Urology Unit and Academic Unit of Molecular Oncology, CR-

UK/YCR, Sheffield Cancer Research Centre, University of Sheffield Medical School, Sheffield, UK

12 Royal Liverpool and Broadgreen Hospitals NHS Trust, Liverpool, UK

13 St James's Hospital Institute of Oncology, Leeds, UK

14 Department of Urology, University of Minnesota, Minneapolis, MN, and Minneapolis VA Health Care System, Minneapolis, MN, USA

15 Department of Clinical Oncology, Aberdeen Royal Infirmary, Aberdeen, UK

16 Newcastle University and Freeman Hospital, Newcastle, UK

17 University of Glasgow, Beatson West of Scotland Cancer Centre, Glasgow, UK

18 Department of Urology, University Hospitals Leicester, Leicester, UK 
19 Department of Urology, Western General Hospital, Lothian University Hospitals, Edinburgh, UK

20 Velindre Hospital, Cardiff, UK

21 Department of Clinical Oncology, Western General Hospital, Edinburgh, UK

22 The Royal Surrey County Hospital, Guildford, Surrey, UK

23 Department of Urology, University Hospital, St. Etienne, France

24 Urology Department, Central Manchester University Hospitals, Manchester, UK

25 Academic Urology Group, University of Cambridge, Addenbrooke's Hospital, Cambridge

Biomedical Campus, Cambridge, UK

26 Department of Urology, Netherlands Cancer Institute, Amsterdam, The Netherlands

27 Academic Urology Unit, University of Aberdeen, Aberdeen, UK

Objective: To develop a core outcome set (COS) applicable for effectiveness trials of all interventions for localised prostate cancer.

Background: Many treatments exist for localised prostate cancer, although it is unclear which offers the optimal therapeutic ratio. This is confounded by inconsistencies in the selection, definition, measurement and reporting of outcomes in clinical trials.

Subjects and methods: A list of 79 outcomes was derived from a systematic review of published localised prostate cancer effectiveness studies and semi-structured interviews with 15 prostate cancer patients. A two-stage consensus process involving 118 patients and 56 international healthcare professionals (HCPs) (cancer specialist nurses, urological surgeons and oncologists) was undertaken, consisting of a three-round Delphi survey followed by a face-to-face consensus panel meeting of $13 \mathrm{HCPs}$ and 8 patients. 
Results: The final COS included 19 outcomes. Twelve apply to all interventions: death from prostate cancer, death from any cause, local disease recurrence, distant disease recurrence/metastases, disease progression, need for salvage therapy, overall quality of life, stress urinary incontinence, urinary function, bowel function, faecal incontinence, sexual function. Seven were interventionspecific: perioperative deaths (surgery), positive surgical margin (surgery), thromboembolic disease (surgery), bothersome or symptomatic urethral or anastomotic stricture (surgery), need for curative treatment (active surveillance), treatment failure (ablative therapy), and side effects of hormonal therapy (hormone therapy). The UK-centric participants may limit the generalisability to other countries, but trialists should reason why the $\cos$ would not be applicable. The default position should not be that a COS developed in one country will automatically not be applicable elsewhere.

Conclusion: We have established a COS for trials of effectiveness in localised prostate cancer, applicable across all interventions which should be measured in all localised prostate cancer effectiveness trials.

\section{Introduction}

Treatments for localised prostate cancer can be associated with side effects such as urinary incontinence, erectile dysfunction or bowel dysfunction. These may be permanent and cause significant impairment of quality of life. (1) The choice between treatments is driven by the therapeutic ratio with a balance between cancer control and the likelihood of experiencing adverse events, speed of return to routine activities and long-term impact on health-related quality of life. $(2,3)$ 
It is therefore critical that outcomes important to all stakeholders are measured and reported. However, many systematic reviews of effectiveness (4-9) and clinical practice guidelines (10) acknowledge the difficulties in synthesising the evidence base due to heterogeneity in outcome selection, definitions, measurement and reporting across different trials.

A potential solution is a "core outcome set" (COS), which is a minimum set of outcomes that should be measured and reported in effectiveness trials in a particular condition. (11) Its use can reduce heterogeneity in outcome selection, measurement and reporting across trials, and facilitate evidence synthesis. $(12,13)$

A 'standard set of patient-centred' outcomes was developed by Martin et al (14). However, Martin et al's purpose was to provide quality indicators for institutional registries, "outside of clinical trials" (15) with which clinicians or hospitals may measure themselves competitively to "drive competition around value". As such, their work was not a COS for effectiveness trials. (14) Furthermore, the inclusion of only two patients in Martin et al's consensus process is unlikely to be sufficient and may have biased any results toward clinician preference. (16) Lastly, the tools used to measure their standard set were not evaluated transparently or robustly with regards to measurement properties and feasibility. (13) It is currently unclear which measures should be used in the outcomes measured in clinical trials.

We report here the results of the development and establishment of a COS for intervention effectiveness trials for localised prostate cancer. The intention was to identify core outcomes which were applicable across all intervention and outcomes which may be intervention-specific. The scope of the project led to the appropriate methods (outlined below) which are advocated by the COMET initiative, $(11,12)$ and are explained further in our study protocol. (17) We report our study in line with the COS-STAR reporting guidance. (18) 


\subsection{Aims and objectives}

The aim was to establish a COS for trials of primary interventions for localised prostate cancer (defined as clinical TNM stage $\leq$ T2NOMO) (19) which is applicable across all interventions, including adjuvant hormonal therapy.

Specific objectives were to:

1. Achieve consensus amongst patients and healthcare professionals on outcomes critically important to decision-making; and

2. Establish a COS for use in future trials assessing interventions for localised prostate cancer.

\section{Materials and Methods}

\subsection{Protocol registration and ethical approval}

The methodology used was that recommended by the COMET Initiative - the international expert body dedicated to the robust development of COS. (20) The study protocol was published (17) and the study approved by the National Research Ethics Service (NRES) - North of Scotland Committee (reference 12/NS0042). A project steering committee was established to provide oversight.

\subsection{Achieving consensus amongst patients and healthcare professionals on critically important outcomes}

The consensus building process was divided into two phases: (1) Delphi survey involving prostate cancer patients in the UK, and healthcare professionals (HCPs) involved in the management of localised prostate cancer across the UK, Europe and the USA; and (2) formal consensus group meeting involving patients and HCPs. 


\subsubsection{Delphi survey}

Delphi surveys are a well-recognised and increasingly-used consensus method for COS development.

(21) A systematic review of the literature was initially performed to ascertain the full range of outcomes that had previously been reported in trials of interventions for localised prostate cancer.

(22) In addition, semi-structured interviews were conducted with a purposive sample of patients to identify any further potentially relevant outcomes. (22) All identified outcomes where entered into a bespoke online Delphi tool, written in C\# using WebForms and a MySQL backend. The full list of outcomes included in the questionnaire (and their definitions) is shown in Appendix 1. Survey participants rated each of the items' importance for decision-making.

Patients and HCPs were chosen because they are important stakeholders in the management of localised prostate cancer. Participants from the UK were primarily targeted due to feasibility and resource issues. Patients were eligible if they had been treated or managed for localised prostate cancer and were identified through the UK-based UCAN charity's prospective patient database (23) and through prostate cancer support groups registered in the UK and listed on the National Federation of Prostate Cancer Support Groups' website. (24) HCPs were identified through the following membership directories and websites: British Association of Urological Surgeons (BAUS), British Association of Urological Nurses (BAUN), European Society for Medical Oncology (ESMO), American Society of Clinical Oncology (ASCO), European Association of Urology Guidelines Office, and the Cochrane Urology group. Purposive sampling was undertaken, covering different treatments, age and time since treatment for patients, and type of HCP (urologist, oncologist, or cancer nurse specialist) and area of expertise (robotic or laparoscopic radical prostatectomy, ablative therapy, external beam radiotherapy, brachytherapy, and active surveillance). 153 patients and 110 HCPs were invited, with an anticipated completion rate of $50 \%$. Informed consent was presumed if participants registered to take part in the online survey. 
The questionnaires and participant information sheets were assessed for face validity in a focus group with 6 patients and 5 HCPs. Three iterative rounds were planned, and after round one, participants were reminded of their own scores and provided with feedback from within their own groups and/or from the other groups. Participants had the opportunity to revise their score, or add further items into the survey for incorporation in the following round. No items were dropped between rounds. Participants were asked to score the importance of each outcome listed on a 9point scale adapted from GRADE (25) (i.e. 1-3 = not important; 4-6 = important; 7-9 = critical; together with an 'unable to score' option).

Descriptive statistics were used to summarise the results of each round, including the percentage of participants scoring each of 1-9 for the outcome. The results for each stakeholder group were analysed and presented separately in each round. After the final round, items scored as critical (i.e. $7-9$ ) by $\geq 70 \%$ of patients and HCPs separately AND not important (i.e. $1-3$ ) by $<15 \%$ of patients and HCPs separately were eligible for inclusion in a preliminary core outcome set (i.e. 'consensus in' outcomes). Conversely, items scored as not important (i.e. $1-3$ ) by $\geq 70 \%$ of patients and HCPs separately and critical (7-9) by $<15 \%$ of patients and HCPs separately were excluded from further analysis (i.e. 'consensus out' outcomes). All other outcomes were classified as 'equivocal'. These scoring thresholds were based prior COS projects. (26-28) All outcomes were available for discussion and voted on at the consensus group meeting.

\subsubsection{Consensus group meeting}

A one-day consensus group meeting was held to review the preliminary coS derived from the Delphi survey, and to discuss, deliberate and vote in order to establish the final COS. Patients and HCPs were purposively sampled from those completing all rounds of the Delphi survey to ensure 
representation of patients receiving the range of treatment types, and urologists, oncologists and cancer nurse specialists. Non-voting observers, a patient and public involvement coordinator (PPI), and non-clinical members of the project steering group also attended. The meeting was chaired by a member of the Steering Group [PRW].

Voting was undertaken anonymously using personalised electronic handsets. (29) All items were individually presented, reviewed, discussed and voted upon regarding their importance for decisionmaking. Participants were asked "Is this outcome important enough to be included in the COS?" and asked to score the outcomes on the same 1-9 scale as the Delphi survey. Items scored as critical (i.e. $7-9$ ) by $\geq 70 \%$ and not important (i.e. $1-3$ ) by $<15 \%$ of voting members were eligible for inclusion in the final COS. The results for an outcome were conveyed to participants immediately after voting, and the final COS was shown to all participants at the end of the meeting.

\section{Results}

An overview of the COS development process and summary of results can be seen in Figure 1.

\subsection{Consensus amongst patients and healthcare professionals on critically important}

\section{outcomes}

\subsubsection{Delphi survey}

The systematic review and patient interviews generated 79 discrete outcomes which were incorporated into an online questionnaire (Appendix 1). A total of 152 participants completed all 3 rounds of the survey. Of these, $47(31 \%)$ were HCPs and 105 (69\%) were patients. The completion rate (i.e. proportion who completed all 3 rounds of the survey out of those invited) was $43 \%$ for HCPs and $69 \%$ for patients. The overall attrition rate (i.e. drop outs between rounds 1 and 3 ) was $13 \%$. We investigated whether attrition may have introduced bias by comparing the mean (SD) round 1 scores for those completing round 1 and round $2(5.9(1.3))$ with those who dropped out after round $1(5.8(1.5))$. We then repeated this for mean (SD) round 2 scores for those completing 
round 2 and $3(6(1.2))$, compared with those who dropped out after round $2(5.7(0.7))$. Those dropping out between rounds did not appear to hold different views, suggesting that there was no attrition bias.

Tables $1 \mathrm{a}$ and $1 \mathrm{~b}$ summarise the treatment/expertise characteristics of the patients and HCPs who completed all 3 rounds of the survey. In addition, the detailed characteristics of HCPs completing all 3 rounds are included in Appendix 2. Five additional outcomes were proposed by participants in round 1 (impact on relationship with partner, bladder pain, urinary tract infection, induction of new cancers, and side effects of hormonal therapy), and these were incorporated into subsequent rounds. Table 2 summarises the results from Delphi survey round three, showing how each outcome was finally scored by patients and HCPs with the results expressed as proportions for each category of 'not important', 'important', and 'critical', for the entire study cohort. The outcomes which fulfilled the criteria for 'consensus in', and 'equivocal' outcomes are indicated. No outcomes met the criteria for 'consensus out'.

\subsubsection{Consensus group meeting}

The consensus group meeting was held at the University of Aberdeen, Scotland on the $22^{\text {nd }}$ February 2016. A total of 21 voting members attended ( 8 patients, 13 HCPs). The list of participants along with their expertise is given in Table 3. For patients, the median [IQR] time since treatment was 3.5 [2.64.3] years. The complete results of the Delphi survey were presented and discussed.

Following discussion, four outcomes (urinary function, bowel function, sexual function and overall quality of life) were grouped back into broader domains. This was done because there was a split vote i.e. that everyone voted some aspect of those domains as critical (7-9) but not all voted for the same aspect. Consequently, this was a pragmatic means of taking into account the heterogeneity of responses from the Delphi survey and consensus meeting in regard to those discrete outcomes Therefore, these multi-dimensional outcomes will need careful consideration of appropriate measurement instruments - which is part of the planned future research. The original categories for 
urinary function, bowel function, sexual function and overall quality of life outcomes before recategorisation can be viewed in Appendix 1.

The results of the voting for each outcome are summarised in Appendix 3. The final core outcome set is summarised in Table 4, along with the interventions each core outcome is relevant to. The final COS contains 19 outcomes, with 12 universal outcomes (i.e. relevant across all interventions) and 7 intervention-specific ones ( 4 for surgery, and one each for active surveillance, cryotherapy/HIFU/ablative therapy, and hormonal therapy).

\section{Discussion}

Our study adopted robust methods to generate a core outcome set relevant to trials of interventions for localised prostate cancer. From the consensus process, 19 core outcomes were identified: 12 universal and 7 intervention-specific, covering all domains of cancer control and survival, urinary function, bowel function, sexual function, quality of life, and adverse events.

There have been two recent reports on developing standardised outcomes in the field of localised prostate cancer. Martin et al. (14) defined a set of health outcomes for localised prostate cancer management, to be measured in routine clinical practice with the purpose of determining the value of health care interventions; (14) and van den Bos et al. (30) reported on a consensus statement regarding the design of future trials of focal ablative therapy for a sub-set of patients with localised prostate cancer. Additional insights provided by our study are that it is the first localised prostate cancer study that takes into account the opinions of patients on a large scale and uses robust and transparent methods planned a priori.

Whilst it is encouraging that there is broad overlap between Martin et al's outcomes recommended for clinical practice and our COS for effectiveness trials, it is important to reiterate the differences in the aims of the two studies, i.e. we aimed to develop a COS for effectiveness trails, Martin et al's standard-set was not designed for trials but for routine clinical practice. It is important also to re- 
state the methodological differences. In particular the involvement of only two patients in Martin et al's consensus process is unlikely to sufficiently capture patient opinion. $(15,16,31)$ Ultimately, it is desirable for routine clinical data and data from trials to be commensurable, particularly in situations where routine data (such as rare events) might be more reliably captured in long-term institutional databases as opposed to the trial setting.

Van den Bos et al's recommended primary outcome measure (negative biopsy at 12 months after treatment) (30) is encompassed within our outcome of treatment failure for ablative therapy in our COS. There are important differences between this study and our COS study. First, our COS study had a broader scope encompassing all current treatments for localised prostate cancer rather than a single type of intervention for a subset of patients with certain disease characteristics. Also, their expert group had no patient representation; the Delphi process does not give adequate information to assess how information was fed back to participants between rounds, and may have influenced subsequent rounds; and it is unclear how consensus was reached in the final meeting. (32)

This study is the most rigorous and largest of its kind, involving a large sample of patients from the UK, and HCPs from the UK, Europe and USA, producing a COS specifically developed for localised prostate cancer intervention trials using rigorous, protocol-driven, transparent and reproducible methods. (17) A comprehensive and robust systematic review to explore, define and characterise the nature of heterogeneity of outcome selection, definition and measurement was performed prior to a consensus-based process involving a Delphi survey and a consensus group meeting. The study involved a large, purposively sampled group of participants which included men with localised prostate cancer, and a diverse group of healthcare professionals from the UK, Europe and the USA. The Delphi survey included three iterative rounds, whereby feedback on others' opinions was provided to allow participants to reflect, and to revise or maintain their responses as required, in addition to proposing any additional outcomes. 
A limitation of the COS is that most of the participants were from the UK. However, we think that people in other countries should look at this well-developed COS and ask the question 'Is there a reason why these results would not be similar to those that could be obtained in our population?' If the answer is yes, then clearly more work is needed, but the default position should not be that a COS developed in one country will automatically not be applicable elsewhere. Additionally, more surgeons completed the survey and participated in the consensus meeting than oncologists. However, the HCP group also consisted of specialist nurses who provided crucially important perspectives regarding treatment with radiotherapy.

We assumed that most potentially important outcomes were likely to be reported in studies representing the highest levels of evidence only, based on the hierarchy of evidence, (33) on the basis that such studies are more likely to guide or change practice, and more likely to measure outcomes using validated tools. Although this may be considered a strength, it can also be regarded as a limitation because some potentially important outcomes may have been missed from our review. However, this risk is minimised by supplementing the long list of potentially important outcomes with additional outcomes identified from the semi-structured patient interviews, and from the Delphi survey where additional outcomes could be added.

The problems and issues arising from inconsistency and heterogeneity of outcome selection, definition, measurement and reporting in primary and secondary studies of localised prostate cancer are well documented. $(4,5,7,34,35)$ Prospective trials of interventions for localised prostate cancer, should consider adopting the COS. Using our COS, future trialists have an opportunity to omit other outcomes which are not 'core', thereby reducing the burden on trialists, patients and funders. Some steps have been directed toward the implementation of the COS inasmuch as the COS is listed in the COMET database and COMET is targeting trial funders (e.g. NIHR guidance) and trialists (e.g. SPIRIT guidelines) to use COS, where they exist for planned trials. 
Additional outcomes beyond the COS proposed (e.g. economic outcomes, related to use of health services, or specific surgical outcomes such as blood loss or anastomotic leak) might need to be measured to address questions beyond relative effectiveness, as these outcomes may be determinants of the cost and effectiveness components of a cost-effectiveness analysis.(36) There is also a valid argument for adopting the COS in clinical practice, since it reflects outcomes of greatest importance to patients and HCPs in making healthcare decisions. There is evidence that COS for trials align very closely with those required for informed consent (37).

Future work should focus on how the COS should be defined and measured in practice, incorporating elements such as standardising outcome definitions and thresholds, identifying the most appropriate measurement instruments, and time points for outcome assessment. We plan to address this in the next phase of our project, based on a strategy of appraising existing outcome measurement tools using objective criteria, such as those outlined in the OMERACT filter (36) or recommended by COSMIN. (13)

In conclusion, our study reports on the robust development of a comprehensive core outcome set for use in trials assessing interventions for localised prostate cancer. The final core outcome set includes 19 core outcomes, with 12 universal and 7 intervention-specific. The routine adoption of this COS in future trials of interventions for localised prostate cancer should ensure that outcomes of importance to patients and healthcare professionals will be collected and thus facilitate comparisons across different studies to allow informed treatment choices for patients, health care professionals and service providers. 


\section{Acknowledgements}

The authors wish to thank the following:

Heather Bagley and Linda Pennet for their advice and assistance regarding patient and public

involvement in research; Janice Forsyth and Sarah Murdoch for their assistance with logistics before and during the consensus meeting; Melanie Harper-Jones and Duncan Appelbe for their support in designing and managing the online Delphi survey and data; Vikki Entwistle for her advice during the protocol development stage; and Jane Blazeby and Liz Gargon for providing advice on Delphi survey and consensus meeting methods. Finally, we would like to thank all patients and HCPs who took part in the interview study and Delphi survey.

\section{References}

1. Daskivich TJ, Lai J, Dick AW, Setodji CM, Hanley JM, Litwin MS, et al. Variation in treatment associated with life expectancy in a population-based cohort of men with early-stage prostate cancer. Cancer. 2014;120(23):3642-50.

2. Lotan Y, Cadeddu JA, Gettman MT. The new economics of radical prostatectomy: cost comparison of open, laparoscopic and robot assisted techniques. The Journal of urology. 2004;172(4 Pt 1):1431-5.

3. Zeliadt SB, Ramsey SD, Penson DF, Hall IJ, Ekwueme DU, Stroud L, et al. Why do men choose one treatment over another?: a review of patient decision making for localized prostate cancer.

Cancer. 2006;106(9):1865-74.

4. Ip S, Dvorak T, Yu WW, Patel K, Obadan N, Chung M, et al. AHRQ Technology Assessments. Comparative Evaluation of Radiation Treatments for Clinically Localized Prostate Cancer: an Update. Rockville (MD): Agency for Healthcare Research and Quality (US); 2010.

5. Ramsay CR, Adewuyi TE, Gray J, Hislop J, Shirley MD, Jayakody S, et al. Ablative therapy for people with localised prostate cancer: a systematic review and economic evaluation. Health Technol Assess. 2015;19(49):1-490.

6. Hegarty J, Beirne PV, Walsh E, Comber H, Fitzgerald T, Wallace Kazer M. Radical prostatectomy versus watchful waiting for prostate cancer. 2010.

7. Wilt TJ, MacDonald R, Rutks I, Shamliyan TA, Taylor BC, Kane RL. Systematic review: comparative effectiveness and harms of treatments for clinically localized prostate cancer. Annals of internal medicine. 2008;148(6):435-48.

8. Ollendorf DA HJ, McMahon P, et al. . Active surveillance and radical prostatectomy for clinically localized, low-risk prostate cancer.; 2009.

9. Ficarra V, Novara G, Artibani W, Cestari A, Galfano A, Graefen M, et al. Retropubic, laparoscopic, and robot-assisted radical prostatectomy: a systematic review and cumulative analysis of comparative studies. European urology. 2009;55(5):1037-63. 
10. Thompson I, Thrasher JB, Aus G, Burnett AL, Canby-Hagino ED, Cookson MS, et al. Guideline for the management of clinically localized prostate cancer: 2007 update. J Urol. 2007;177(6):2106-

31.

11. Williamson P, Altman D, Blazeby J, Clarke M, Gargon E. Driving up the quality and relevance of research through the use of agreed core outcomes. J Health Serv Res Policy. 2012;17(1):1-2.

12. Williamson PR, Altman DG, Blazeby JM, Clarke M, Devane D, Gargon E, et al. Developing core outcome sets for clinical trials: issues to consider. Trials. 2012;13(1):1.

13. Prinsen CA, Vohra S, Rose MR, Boers M, Tugwell P, Clarke M, et al. How to select outcome measurement instruments for outcomes included in a "Core Outcome Set" - a practical guideline. Trials. 2016;17(1):449.

14. Martin NE, Massey L, Stowell C, Bangma C, Briganti A, Bill-Axelson A, et al. Defining a Standard Set of Patient-centered Outcomes for Men with Localized Prostate Cancer. European Urology. 2015;67(3):460-7.

15. Martin NE, Stowell C, Huland H. Reply to Steven MacLennan, Paula R. Williamson, and Thomas B. Lam's Letter to the Editor re: Neil E. Martin, Laura Massey, Caleb Stowell, et al. Defining a Standard Set of Patient-centered Outcomes for Men with Localized Prostate Cancer. Eur Urol 2015;67:460-7. Eur Urol. 2015;68(6):e125-6.

16. MacLennan S, Williamson PR, Lam TB. Re: Neil E. Martin, Laura Massey, Caleb Stowell, et al. Defining a Standard Set of Patient-centered Outcomes for Men with Localized Prostate Cancer. Eur Urol 2015;67:460-7. European Urology. 2016;68(6).

17. MacLennan S, Bekema HJ, Williamson PR, Campbell MK, Stewart F, MacLennan SJ, et al. A core outcome set for localised prostate cancer effectiveness trials: protocol for a systematic review of the literature and stakeholder involvement through interviews and a Delphi survey. Trials. 2015;16(1):76-.

18. Kirkham JJ, Gorst S, Altman DG, Blazeby JM, Clarke M, Devane D, et al. Core Outcome SetSTAndards for Reporting: The COS-STAR Statement. PLoS Med. 2016;13(10):e1002148.

19. Leslie H. Sobin (Editor) MKGE, Christian Wittekind (Editor). TNM Classification of Malignant Tumours, 7th Edition2009 November 2009, Wiley-Blackwell. 336 p.

20. COMET. Home: Core Outcome Measures in Effectiveness Trials Initiative (COMET) [Available from: http://www.comet-initiative.org/.

21. Gorst SL, Gargon E, Clarke M, Blazeby JM, Altman DG, Williamson PR. Choosing Important Health Outcomes for Comparative Effectiveness Research: An Updated Review and User Survey. PLoS One. 2016;11(1):e0146444.

22. Maclennan SL, TBL. MacLennan, SJ. and N'Dow. J. Developing a core outcome set for localised prostate cancer effectivenes trials: Study outline and early results. COMET III; Pontificia Università Lateranense, Rome, Italy2014.

23. UCAN Urological Cancer Charity 2016 [Available from: http://www.ucanhelp.org.uk/. 24. NFPCwebsite. National Federation of Prostate Cancer Support Groups [Available from: http://www.tackleprostate.org/member-organisations.php.

25. Guyatt GH, Oxman AD, Kunz R, Vist GE, Falck-Ytter Y, Schünemann HJ. What is "quality of evidence" and why is it important to clinicians? 2008.

26. Bruce I, Harman N, Williamson P, Tierney S, Callery P, Mohiuddin S, et al. The management of Otitis Media with Effusion in children with cleft palate (mOMEnt): a feasibility study and economic evaluation. 2015.

27. McNair AG, Whistance RN, Forsythe RO, Macefield R, Rees J, Pullyblank AM, et al. Core Outcomes for Colorectal Cancer Surgery: A Consensus Study. PLoS Med. 2016;13(8):e1002071.

28. Potter S, Holcombe C, Ward JA, Blazeby JM. Development of a core outcome set for research and audit studies in reconstructive breast surgery. The British journal of surgery. 2015;102(11):136071.

29. Banxia. Student response systems. 2016. 
30. van den Bos W, Muller BG, de Bruin DM, de Castro Abreu AL, Chaussy C, Coleman JA, et al. Salvage ablative therapy in prostate cancer: international multidisciplinary consensus on trial design. Urol Oncol. 2015;33(11):495.e1-7.

31. Wittmann D, Skolarus TA. Re: Neil E. Martin, Laura Massey, Caleb Stowell, et al. Defining a Standard Set of Patient-centered Outcomes for Men with Localized Prostate Cancer. Eur Urol 2015;67:460-7. Eur Urol. 2016;69(6):e125-6.

32. Blazeby JM. Consistency in design and collaboration in delivery: key to successful randomised controlled trials in focal therapy for prostate cancer. Eur Urol. 2014;65(6):1084-5.

33. Bob Phillips CBDSDBSSBHMDsNUbJHM. Oxford Centre for Evidence-based Medicine - Levels of Evidence (March 2009) - CEBM.

34. Ramsay C, Pickard R, Robertson C, Close A, Vale L, Armstrong N. Systematic review and economic modelling of the relative clinical benefit and cost-effectiveness of laparoscopic surgery and robotic surgery for removal of the prostate in men with localised prostate cancer. 2012;16(41).

35. Budaus L, Bolla M, Bossi A, Cozzarini C, Crook J, Widmark A, et al. Functional outcomes and complications following radiation therapy for prostate cancer: a critical analysis of the literature. Eur Urol. 2012;61(1):112-27.

36. Boers M, Kirwan JR, Wells G, Beaton D, Gossec L, d'Agostino MA, et al. Developing core outcome measurement sets for clinical trials: OMERACT filter 2.0. J Clin Epidemiol. 2014;67(7):74553.

37. McNair. A WR, Macefiled. R, Brookes. S, Blazeby. J. Do Patients want to know what Surgeons Tell Them before Colorectal Cancer Surgery? A Comparison of Surgeons' and Patients' Views of Important Information for Informed Consent. British Journal of Surgery: John Wiley \& Sons, Ltd; 2016. p. 29. 
Table 1a: Summary of characteristics of patients who completed all three rounds of the Delphi survey

\begin{tabular}{|c|c|c|c|c|c|c|c|c|c|c|c|c|}
\hline \multicolumn{13}{|c|}{ Patients ( $\mathrm{N}=105)$} \\
\hline \multicolumn{2}{|c|}{ Age N (\%) } & \multicolumn{5}{|c|}{ Primary treatment $\mathbf{N}(\%)$} & \multicolumn{3}{|c|}{$\begin{array}{c}\text { Time since } \\
\text { treatment } \mathrm{N}(\%)\end{array}$} & \multicolumn{3}{|c|}{ Country of origin $\mathrm{N}(\%)$} \\
\hline $\begin{array}{c}\leq 60 \\
\text { yea } \\
\text { rs }\end{array}$ & $\begin{array}{c}>60 \\
\text { yea } \\
\text { rs }\end{array}$ & $\begin{array}{c}\text { Surge } \\
\text { ry }\end{array}$ & $\begin{array}{c}\text { EBR } \\
T\end{array}$ & $\begin{array}{c}\text { Brachyther } \\
\text { apy }\end{array}$ & AS & $\begin{array}{l}\text { Ablati } \\
\text { ve } \\
\text { thera } \\
\text { py }\end{array}$ & $\begin{array}{l}\leq 1 \\
\text { ye } \\
\text { ar }\end{array}$ & $\begin{array}{c}2-5 \\
\text { yea } \\
\text { rs }\end{array}$ & $\begin{array}{c}>5 \\
\text { yea } \\
\text { rs }\end{array}$ & $\begin{array}{l}\text { Scotla } \\
\text { nd }\end{array}$ & $\begin{array}{c}\text { Engla } \\
\text { nd }\end{array}$ & $\begin{array}{c}\text { Wal } \\
\text { es }\end{array}$ \\
\hline $\begin{array}{c}19 \\
(18)\end{array}$ & $\begin{array}{c}86 \\
(82)\end{array}$ & $\begin{array}{c}50 \\
(48)\end{array}$ & $\begin{array}{c}26 \\
(25)\end{array}$ & $7(7)$ & $\begin{array}{l}17 \\
(1 \\
6)\end{array}$ & $5(5)$ & $\begin{array}{c}17 \\
(16 \\
)\end{array}$ & $\begin{array}{c}53 \\
(51)\end{array}$ & $\begin{array}{c}35 \\
(33)\end{array}$ & $20(19)$ & $\begin{array}{c}72 \\
(69)\end{array}$ & $\begin{array}{c}13 \\
(12)\end{array}$ \\
\hline
\end{tabular}

Table 1b: Summary of characteristics of HCPs who completed all three rounds of the Delphi survey

\begin{tabular}{|c|c|c|c|c|c|c|c|}
\hline \multicolumn{3}{|c|}{ HCPs (N = 47) } \\
\hline \multicolumn{3}{|c|}{ Expertise N (\%) } & \multicolumn{5}{c|}{ Country of origin N (\%) } \\
\hline CNS & $\begin{array}{c}\text { Urological } \\
\text { surgeon }\end{array}$ & Oncologist & Scotland & England & Wales & $\begin{array}{c}\text { Other European } \\
\text { countries }\end{array}$ & USA \\
\hline $\begin{array}{c}\text { con } \\
(17)\end{array}$ & $31(66)$ & $8(17)$ & $25(53)$ & $12(26)$ & $1(2)$ & $7(15)$ & 2 \\
$(4)$
\end{tabular}

Abbreviations: HCPs (health care professionals) CNS (cancer nurse specialist), EBRT (electron beam radiotherapy), AS (active surveillance) 
Table 2: Summary of results after three rounds of Delphi survey

\begin{tabular}{|c|c|c|c|c|c|c|c|}
\hline \multirow[b]{2}{*}{ Outcomes } & \multicolumn{3}{|c|}{ Patients N = 105} & \multicolumn{3}{|c|}{ HCPs $N=47$} & \multirow{2}{*}{$\begin{array}{l}\text { Consensus } \\
\text { from Delphi } \\
\text { survey }\end{array}$} \\
\hline & $\begin{array}{c}\text { Not } \\
\text { important }\end{array}$ & Important & Critical & $\begin{array}{c}\text { Not } \\
\text { important }\end{array}$ & Important & Critical & \\
\hline \multicolumn{8}{|c|}{ A.CANCER SPECIFIC AND SURVIVAL OUTCOMES } \\
\hline 1. Death from any cause & $2 \%$ & $6 \%$ & $92 \%$ & $0 \%$ & $2 \%$ & $98 \%$ & In \\
\hline 2. Death from prostate cancer & $1 \%$ & $4 \%$ & $95 \%$ & $0 \%$ & $2 \%$ & $98 \%$ & In \\
\hline 3. Death from causes other than prostate cancer* & $2 \%$ & $9 \%$ & $89 \%$ & $0 \%$ & $6 \%$ & $94 \%$ & In \\
\hline 4. Local disease recurrence & $1 \%$ & $5 \%$ & $94 \%$ & $0 \%$ & $4 \%$ & $96 \%$ & In \\
\hline 5. Distant disease recurrence/metastases & $1 \%$ & $3 \%$ & $96 \%$ & $0 \%$ & $0 \%$ & $100 \%$ & In \\
\hline 6. Disease progression (disease getting worse) & $2 \%$ & $5 \%$ & $93 \%$ & $0 \%$ & $4 \%$ & $96 \%$ & In \\
\hline 7. Need for further treatment to augment primary treatment & $2 \%$ & $10 \%$ & $88 \%$ & $0 \%$ & $19 \%$ & $81 \%$ & In \\
\hline 8. Need for salvage therapy & $3 \%$ & $6 \%$ & $91 \%$ & $0 \%$ & $13 \%$ & $87 \%$ & In \\
\hline \multicolumn{8}{|c|}{ Applicable to active surveillance } \\
\hline 9. Disease reclassification & $5 \%$ & $6 \%$ & $89 \%$ & $0 \%$ & $23 \%$ & $77 \%$ & In \\
\hline 10. Need for curative treatment & $5 \%$ & $9 \%$ & $86 \%$ & $0 \%$ & $4 \%$ & $96 \%$ & In \\
\hline \multicolumn{8}{|c|}{ Applicable to ablative procedures (cryotherapy, HIFU) } \\
\hline 11. Treatment failure & $4 \%$ & $4 \%$ & $93 \%$ & $0 \%$ & $11 \%$ & $89 \%$ & In \\
\hline 12. Retreatment & $4 \%$ & $8 \%$ & $88 \%$ & $0 \%$ & $19 \%$ & $81 \%$ & In \\
\hline \multicolumn{8}{|c|}{ Applicable to surgery } \\
\hline 13. Positive surgical margin & $3 \%$ & $5 \%$ & $92 \%$ & $4 \%$ & $49 \%$ & $47 \%$ & Equivocal \\
\hline \multicolumn{8}{|c|}{ B. BOWEL FUNCTION } \\
\hline 14. Diarrhoea & $7 \%$ & $82 \%$ & $11 \%$ & $2 \%$ & $87 \%$ & $11 \%$ & Equivocal \\
\hline 15. Faecal incontinence & $4 \%$ & $19 \%$ & $77 \%$ & $2 \%$ & $9 \%$ & $89 \%$ & In \\
\hline 16. Faecal urgency & $4 \%$ & $57 \%$ & $39 \%$ & $2 \%$ & $63 \%$ & $35 \%$ & Equivocal \\
\hline
\end{tabular}




\begin{tabular}{|c|c|c|c|c|c|c|c|}
\hline 17. Rectal bleeding & $6 \%$ & $38 \%$ & $56 \%$ & $4 \%$ & $57 \%$ & $39 \%$ & Equivocal \\
\hline 18. Rectal itch & $15 \%$ & $79 \%$ & $6 \%$ & $15 \%$ & $80 \%$ & $4 \%$ & Equivocal \\
\hline 19. Constipation & $10 \%$ & $80 \%$ & $9 \%$ & $11 \%$ & $85 \%$ & $4 \%$ & Equivocal \\
\hline 20. Bowel frequency & $13 \%$ & $83 \%$ & $4 \%$ & $7 \%$ & $85 \%$ & $9 \%$ & Equivocal \\
\hline 21. Painful bowel movements & $9 \%$ & $64 \%$ & $27 \%$ & $2 \%$ & $83 \%$ & $15 \%$ & Equivocal \\
\hline \multicolumn{8}{|c|}{ C. URINARY FUNCTION } \\
\hline 22. Urge incontinence & $6 \%$ & $44 \%$ & $50 \%$ & $0 \%$ & $43 \%$ & $57 \%$ & Equivocal \\
\hline 23. Stress incontinence & $7 \%$ & $60 \%$ & $33 \%$ & $0 \%$ & $49 \%$ & $51 \%$ & Equivocal \\
\hline 24. Weak urine stream & $10 \%$ & $79 \%$ & $11 \%$ & $7 \%$ & $87 \%$ & $7 \%$ & Equivocal \\
\hline 25. Nocturia & $26 \%$ & $60 \%$ & $14 \%$ & $7 \%$ & $87 \%$ & $7 \%$ & Equivocal \\
\hline 26. Haematuria & $11 \%$ & $37 \%$ & $52 \%$ & $9 \%$ & $83 \%$ & $9 \%$ & Equivocal \\
\hline 27. Dysuria & $9 \%$ & $53 \%$ & $38 \%$ & $2 \%$ & $91 \%$ & $7 \%$ & Equivocal \\
\hline 28. Frequency & $17 \%$ & $68 \%$ & $14 \%$ & $11 \%$ & $83 \%$ & $7 \%$ & Equivocal \\
\hline 29. Urgency & $11 \%$ & $67 \%$ & $22 \%$ & $2 \%$ & $89 \%$ & $9 \%$ & Equivocal \\
\hline 30. Need for a temporary urethral catheter & $27 \%$ & $34 \%$ & $39 \%$ & $23 \%$ & $72 \%$ & $4 \%$ & Equivocal \\
\hline 31. Catheter-related problems & $10 \%$ & $40 \%$ & $49 \%$ & $13 \%$ & $79 \%$ & $9 \%$ & Equivocal \\
\hline \multicolumn{8}{|c|}{ D. SEXUAL FUNCTION } \\
\hline 32. Erectile dysfunction & $10 \%$ & $52 \%$ & $38 \%$ & $0 \%$ & $68 \%$ & $32 \%$ & Equivocal \\
\hline 33. Reduced or loss of libido & $8 \%$ & $66 \%$ & $26 \%$ & $0 \%$ & $94 \%$ & $6 \%$ & Equivocal \\
\hline 34. Frequency of intercourse & $14 \%$ & $72 \%$ & $14 \%$ & $9 \%$ & $89 \%$ & $2 \%$ & Equivocal \\
\hline 35. Ejaculatory function & $18 \%$ & $60 \%$ & $22 \%$ & $21 \%$ & $79 \%$ & $0 \%$ & Equivocal \\
\hline 36. Orgasmic function & $10 \%$ & $63 \%$ & $27 \%$ & $2 \%$ & $98 \%$ & $0 \%$ & Equivocal \\
\hline 37. Sexual function & $10 \%$ & $61 \%$ & $29 \%$ & $0 \%$ & $83 \%$ & $17 \%$ & Equivocal \\
\hline \multicolumn{8}{|c|}{ E. OPERATION SPECIFIC AND HOSPITAL-STAY OUTCOMES } \\
\hline \multicolumn{8}{|c|}{ Applicable to all treatments apart from Active surveillance } \\
\hline 38. Duration of the procedure & $39 \%$ & $57 \%$ & $4 \%$ & $49 \%$ & $51 \%$ & $0 \%$ & Equivocal \\
\hline
\end{tabular}




\begin{tabular}{|c|c|c|c|c|c|c|c|}
\hline 39. Pain & $10 \%$ & $82 \%$ & $8 \%$ & $0 \%$ & $100 \%$ & $0 \%$ & Equivocal \\
\hline 40. Use of pain relief medications after procedure & $8 \%$ & $82 \%$ & $10 \%$ & $9 \%$ & $91 \%$ & $0 \%$ & Equivocal \\
\hline 41. Catheter duration & $13 \%$ & $71 \%$ & $16 \%$ & $17 \%$ & $83 \%$ & $0 \%$ & Equivocal \\
\hline 42. Duration of hospital stay & $34 \%$ & $61 \%$ & $5 \%$ & $13 \%$ & $87 \%$ & $0 \%$ & Equivocal \\
\hline 43. Time to full recovery & $14 \%$ & $71 \%$ & $15 \%$ & $0 \%$ & $52 \%$ & $48 \%$ & Equivocal \\
\hline 44. Time to partial recovery & $17 \%$ & $76 \%$ & $7 \%$ & $4 \%$ & $93 \%$ & $2 \%$ & Equivocal \\
\hline \multicolumn{8}{|c|}{ Applicable to radical prostatectomy only } \\
\hline 45. Blood loss & $18 \%$ & $56 \%$ & $26 \%$ & $2 \%$ & $82 \%$ & $16 \%$ & Equivocal \\
\hline \multicolumn{8}{|c|}{ F. QUALITY OF LIFE AND EMOTIONAL WELL-BEING } \\
\hline 46. Anxiety & $14 \%$ & $78 \%$ & $9 \%$ & $2 \%$ & $89 \%$ & $9 \%$ & Equivocal \\
\hline 47. Depression & $12 \%$ & $69 \%$ & $19 \%$ & $2 \%$ & $89 \%$ & $9 \%$ & Equivocal \\
\hline 48. Lack of confidence & $16 \%$ & $73 \%$ & $11 \%$ & $2 \%$ & $89 \%$ & $9 \%$ & Equivocal \\
\hline 49. Feeling less masculine & $27 \%$ & $61 \%$ & $12 \%$ & $2 \%$ & $91 \%$ & $6 \%$ & Equivocal \\
\hline 50. Feeling tired or fatigued & $10 \%$ & $73 \%$ & $17 \%$ & $0 \%$ & $94 \%$ & $6 \%$ & Equivocal \\
\hline 51. Overall Quality of LIfe & $11 \%$ & $52 \%$ & $37 \%$ & $0 \%$ & $40 \%$ & $60 \%$ & Equivocal \\
\hline 52. Quality of life relating to urinary function & $8 \%$ & $56 \%$ & $37 \%$ & $0 \%$ & $49 \%$ & $51 \%$ & Equivocal \\
\hline 53. Quality of life relating to sexual function & $8 \%$ & $64 \%$ & $28 \%$ & $0 \%$ & $77 \%$ & $23 \%$ & Equivocal \\
\hline 54. Quality of life relating to bowel function & $6 \%$ & $48 \%$ & $45 \%$ & $0 \%$ & $49 \%$ & $51 \%$ & Equivocal \\
\hline 55. Quality of life impact on immediate family & $6 \%$ & $56 \%$ & $38 \%$ & $0 \%$ & $79 \%$ & $21 \%$ & Equivocal \\
\hline \multicolumn{8}{|c|}{ G. ADVERSE EVENTS DURING AND AFTER HORMONE THERAPY } \\
\hline 56. Hot flushes & $26 \%$ & $72 \%$ & $2 \%$ & $4 \%$ & $91 \%$ & $4 \%$ & Equivocal \\
\hline 57. Swelling of the breast tissue (gynaecomastia) & $17 \%$ & $70 \%$ & $13 \%$ & $4 \%$ & $87 \%$ & $9 \%$ & Equivocal \\
\hline 58. Loss of libido & $16 \%$ & $70 \%$ & $14 \%$ & $2 \%$ & $98 \%$ & $0 \%$ & Equivocal \\
\hline 59. Erectile dysfunction & $17 \%$ & $53 \%$ & $29 \%$ & $2 \%$ & $85 \%$ & $13 \%$ & Equivocal \\
\hline 60. Body fat gain & $7 \%$ & $76 \%$ & $17 \%$ & $4 \%$ & $91 \%$ & $4 \%$ & Equivocal \\
\hline 61. Fatigue & $3 \%$ & $77 \%$ & $21 \%$ & $2 \%$ & $81 \%$ & $17 \%$ & Equivocal \\
\hline
\end{tabular}


H. ADVERSE EVENTS DURING AND AFTER RADIATION THERAPY

\begin{tabular}{|l|r|r|r|r|r|r|r|}
\hline 62. Anal discomfort & $8 \%$ & $82 \%$ & $10 \%$ & $0 \%$ & $96 \%$ & $4 \%$ & Equivocal \\
\hline 63. Urethral stricture & $8 \%$ & $21 \%$ & $71 \%$ & $0 \%$ & $47 \%$ & $53 \%$ & Equivocal \\
\hline 64. Radiation proctitis & $9 \%$ & $52 \%$ & $39 \%$ & $0 \%$ & $53 \%$ & $47 \%$ & Equivocal \\
\hline 65. Acute urinary retention & $12 \%$ & $8 \%$ & $80 \%$ & $0 \%$ & $45 \%$ & $55 \%$ & Equivocal \\
\hline 66. Fatigue & $7 \%$ & $84 \%$ & $9 \%$ & $0 \%$ & $81 \%$ & $19 \%$ & Equivocal \\
\hline 67. Haematuria & $15 \%$ & $60 \%$ & $25 \%$ & $4 \%$ & $77 \%$ & $19 \%$ & Equivocal \\
\hline
\end{tabular}

I. ADVERSE EVENTS DURING AND AFTER SURGERY

\begin{tabular}{|c|c|c|c|c|c|c|c|}
\hline 68. Acute or sub-acute bowel obstruction & $10 \%$ & $8 \%$ & $82 \%$ & $0 \%$ & $29 \%$ & $71 \%$ & $\ln$ \\
\hline 69. Acute urinary retention & $6 \%$ & $14 \%$ & $80 \%$ & $0 \%$ & $42 \%$ & $58 \%$ & Equivocal \\
\hline 70. Anastomotic leak & $8 \%$ & $18 \%$ & $74 \%$ & $0 \%$ & $64 \%$ & $36 \%$ & Equivocal \\
\hline 71. Blood transfusion & $11 \%$ & $42 \%$ & $47 \%$ & $2 \%$ & $64 \%$ & $33 \%$ & Equivocal \\
\hline 72. Wound problems & $8 \%$ & $38 \%$ & $55 \%$ & $2 \%$ & $89 \%$ & $9 \%$ & Equivocal \\
\hline 73. Bowel injury & $6 \%$ & $13 \%$ & $81 \%$ & $0 \%$ & $11 \%$ & $89 \%$ & $\ln$ \\
\hline 74. Nerve damage or neuropraxia & $8 \%$ & $20 \%$ & $72 \%$ & $0 \%$ & $53 \%$ & $47 \%$ & Equivocal \\
\hline 75. Perioperative deaths & $7 \%$ & $1 \%$ & $91 \%$ & $0 \%$ & & $100 \%$ & $\ln$ \\
\hline 76. Prolonged indwelling catheter & $6 \%$ & $31 \%$ & $63 \%$ & $7 \%$ & $80 \%$ & $13 \%$ & Equivocal \\
\hline 77. Thromboembolic disease & $8 \%$ & $3 \%$ & $89 \%$ & $0 \%$ & $11 \%$ & $89 \%$ & In \\
\hline 78. Rectourethral fistula & $8 \%$ & $5 \%$ & $88 \%$ & $0 \%$ & $4 \%$ & $96 \%$ & In \\
\hline 79. Urethral or anastomotic stricture & $6 \%$ & $12 \%$ & $83 \%$ & $0 \%$ & $24 \%$ & $76 \%$ & $\ln$ \\
\hline
\end{tabular}

80. Impact on relationship with partner

81. Bladder pain

82. Urinary tract infection

83. Induction of new cancers+

84. Side effects of hormonal therapy

\begin{tabular}{|r|r|r|r|r|r|r|}
\hline $10 \%$ & $45 \%$ & $46 \%$ & $0 \%$ & $57 \%$ & $43 \%$ & Equivocal \\
\hline $19 \%$ & $45 \%$ & $36 \%$ & $2 \%$ & $89 \%$ & $9 \%$ & Equivocal \\
\hline $19 \%$ & $46 \%$ & $36 \%$ & $6 \%$ & $89 \%$ & $4 \%$ & Equivocal \\
\hline $6 \%$ & $5 \%$ & $86 \%$ & $2 \%$ & $53 \%$ & $45 \%$ & Equivocal \\
\hline
\end{tabular}


Key: Green cells indicate outcomes meeting consensus 'in'. Red cells indicate $\geq 70 \%$ critical

*'Death from causes other than prostate cancer' was originally voted 'in', but after discussion it was felt to be structurally related to 'death from any cause' and 'death from prostate cancer' and therefore voted out.

+'Induction of new cancers' was originally voted 'in' but after discussion it was felt to be too rare and late occurring an outcome to be feasibly collected in a trial setting and therefore voted out. 
Table 3: Expertise and experience of consensus meeting participants

\begin{tabular}{|c|c|c|c|c|}
\hline Name & Role & Expertise/Experience & $\begin{array}{c}\text { Date of } \\
\text { treatment } \\
\text { start }\end{array}$ & City, country \\
\hline $\begin{array}{l}\text { Gary } \\
\text { Akehurst }\end{array}$ & Patient & $\begin{array}{l}\text { Received treatment for } \\
\text { localised prostate cancer }\end{array}$ & $\begin{array}{l}\text { November } \\
2011\end{array}$ & England (UK) \\
\hline $\begin{array}{l}\text { Robert } \\
\text { Almquist }\end{array}$ & Patient & $\begin{array}{l}\text { Received treatment for } \\
\text { localised prostate cancer }\end{array}$ & $\begin{array}{l}\text { November } \\
2013\end{array}$ & England (UK) \\
\hline Karl Beck & Patient & $\begin{array}{l}\text { Received treatment for } \\
\text { localised prostate cancer }\end{array}$ & $\begin{array}{l}\text { January } \\
2008\end{array}$ & $\begin{array}{l}\text { Scotland } \\
\text { (UK) }\end{array}$ \\
\hline David Budd & Patient & $\begin{array}{l}\text { Received treatment for } \\
\text { localised prostate cancer }\end{array}$ & June 2013 & $\begin{array}{l}\text { Scotland } \\
\text { (UK) }\end{array}$ \\
\hline $\begin{array}{l}\text { Alexander } \\
\text { Ewen }\end{array}$ & Patient & $\begin{array}{l}\text { Received treatment for } \\
\text { localised prostate cancer }\end{array}$ & $\begin{array}{l}\text { November } \\
2013\end{array}$ & $\begin{array}{l}\text { Scotland } \\
\text { (UK) }\end{array}$ \\
\hline David Hurst & Patient & $\begin{array}{l}\text { Received treatment for } \\
\text { localised prostate cancer }\end{array}$ & $\begin{array}{l}\text { September } \\
2011\end{array}$ & England (UK) \\
\hline $\begin{array}{l}\text { Andrew } \\
\text { Mackie }\end{array}$ & Patient & $\begin{array}{l}\text { Received treatment for } \\
\text { localised prostate cancer }\end{array}$ & June 2012 & $\begin{array}{l}\text { Scotland } \\
\text { (UK) }\end{array}$ \\
\hline $\begin{array}{l}\text { Hans } \\
\text { Schreuder }\end{array}$ & Patient & $\begin{array}{l}\text { Received treatment for } \\
\text { localised prostate cancer }\end{array}$ & $\begin{array}{l}\text { October } \\
2012\end{array}$ & England (UK) \\
\hline $\begin{array}{l}\text { Hashim } \\
\text { Ahmed }\end{array}$ & HCP (Surgeon) & HIFU & NA & $\begin{array}{l}\text { London, } \\
\text { England (UK) }\end{array}$ \\
\hline $\begin{array}{l}\text { James } \\
\text { N'Dow }\end{array}$ & $\begin{array}{l}\text { HCP (Surgeon)/ } \\
\text { European Association } \\
\text { of Urology Guidelines } \\
\text { Office }\end{array}$ & $\begin{array}{l}\text { Surgery and active } \\
\text { surveillance/ Chair of EAU } \\
\text { Guidelines Office }\end{array}$ & NA & $\begin{array}{l}\text { Aberdeen, } \\
\text { Scotland } \\
\text { (UK) }\end{array}$ \\
\hline Judith Grant & $\begin{array}{l}\text { HCP (Clinical } \\
\text { Oncologist) }\end{array}$ & EBRT and active surveillance & NA & $\begin{array}{l}\text { Aberdeen, } \\
\text { Scotland } \\
\text { (UK) }\end{array}$ \\
\hline $\begin{array}{l}\text { Justine } \\
\text { Royle }\end{array}$ & HCP (Surgeon) & $\begin{array}{l}\text { Robotic/laparoscopic radical } \\
\text { prostatectomy }\end{array}$ & NA & $\begin{array}{l}\text { Aberdeen, } \\
\text { Scotland } \\
\text { (UK) }\end{array}$ \\
\hline
\end{tabular}




\begin{tabular}{|c|c|c|c|c|}
\hline $\begin{array}{l}\text { Kevin } \\
\text { Wardlaw }\end{array}$ & $\mathrm{HCP}(\mathrm{CNS})$ & Prostate cancer management & NA & $\begin{array}{l}\text { Aberdeen, } \\
\text { Scotland } \\
\text { (UK) }\end{array}$ \\
\hline $\begin{array}{l}\text { Nicolas } \\
\text { Mottet }\end{array}$ & $\begin{array}{l}\text { HCP } \\
\text { (Surgeon)/European } \\
\text { Association of Urology } \\
\text { Prostate cancer } \\
\text { guideline panel }\end{array}$ & $\begin{array}{l}\text { Laparoscopic radical } \\
\text { prostatectomy/Chair of EAU } \\
\text { Prostate cancer guideline } \\
\text { panel }\end{array}$ & NA & $\begin{array}{l}\text { St. Etienne, } \\
\text { France }\end{array}$ \\
\hline $\begin{array}{l}\text { Philip } \\
\text { Cornford }\end{array}$ & $\begin{array}{l}\text { HCP } \\
\text { (Surgeon)/European } \\
\text { Association of Urology } \\
\text { Prostate cancer } \\
\text { guideline panel }\end{array}$ & $\begin{array}{l}\text { Robotic radical } \\
\text { prostatectomy/Co-chair of } \\
\text { EAU Prostate cancer guideline } \\
\text { panel }\end{array}$ & NA & $\begin{array}{l}\text { Liverpool, } \\
\text { England (UK) }\end{array}$ \\
\hline Philip Dahm & $\begin{array}{l}\text { HCP } \\
\text { (Surgeon)/Cochrane } \\
\text { Urology editorial } \\
\text { group }\end{array}$ & $\begin{array}{l}\text { Open radical } \\
\text { prostatectomy/Coordinating } \\
\text { Editor of Cochrane Urology }\end{array}$ & NA & $\begin{array}{l}\text { Minneapolis, } \\
\text { USA }\end{array}$ \\
\hline Rakesh Heer & HCP (Surgeon) & Robotic radical prostatectomy & NA & $\begin{array}{l}\text { Newcastle, } \\
\text { England (UK) }\end{array}$ \\
\hline Rob Jones & $\begin{array}{l}\text { HCP (Medical } \\
\text { Oncologist)/Cancer } \\
\text { Research UK Clinical } \\
\text { Trials Unit }\end{array}$ & $\begin{array}{l}\text { Active surveillance, Director of } \\
\text { CRUK CTU, Beatson Institute }\end{array}$ & NA & $\begin{array}{l}\text { Glasgow, } \\
\text { Scotland } \\
\text { (UK) }\end{array}$ \\
\hline $\begin{array}{l}\text { Sam } \\
\text { McClinton }\end{array}$ & HCP (Surgeon) & $\begin{array}{l}\text { Surgery and active } \\
\text { surveillance }\end{array}$ & NA & $\begin{array}{l}\text { Aberdeen, } \\
\text { Scotland } \\
\text { (UK) }\end{array}$ \\
\hline Thomas Lam & HCP (Surgeon) & $\begin{array}{l}\text { Robotic/laparoscopic radical } \\
\text { prostatectomy }\end{array}$ & NA & $\begin{array}{l}\text { Aberdeen, } \\
\text { Scotland } \\
\text { (UK) }\end{array}$ \\
\hline $\begin{array}{l}\text { William } \\
\text { Cross }\end{array}$ & HCP (Surgeon) & Robotic radical prostatectomy & NA & $\begin{array}{l}\text { Leeds, } \\
\text { England (UK) }\end{array}$ \\
\hline $\begin{array}{l}\text { Marion } \\
\text { Campbell }\end{array}$ & $\begin{array}{l}\text { Methodologist (Non- } \\
\text { voting)/Health } \\
\text { Services Research Unit }\end{array}$ & $\begin{array}{l}\text { Evidence synthesis and } \\
\text { trials/Chair of Health Services } \\
\text { Research Unit, Aberdeen }\end{array}$ & NA & $\begin{array}{l}\text { Aberdeen, } \\
\text { Scotland } \\
\text { (UK) }\end{array}$ \\
\hline $\begin{array}{l}\text { Paula } \\
\text { Williamson }\end{array}$ & $\begin{array}{l}\text { Chair } \\
\text { Methodologist (Non- }\end{array}$ & $\begin{array}{l}\text { Evidence synthesis, trials and } \\
\text { COS/Chair of COMET Initiative } \\
\text { Management Group }\end{array}$ & NA & $\begin{array}{l}\text { Liverpool, } \\
\text { England (UK) }\end{array}$ \\
\hline
\end{tabular}




\begin{tabular}{|l|l|l|l|l|}
\hline & voting)/COMET & & & \\
\hline $\begin{array}{l}\text { Steven } \\
\text { MacLennan }\end{array}$ & $\begin{array}{l}\text { Methodologist (Non- } \\
\text { voting) }\end{array}$ & $\begin{array}{l}\text { Evidence Synthesis and } \\
\text { qualitative research }\end{array}$ & NA & $\begin{array}{l}\text { Aberdeen, } \\
\text { Scotland } \\
\text { (UK) }\end{array}$ \\
\hline $\begin{array}{l}\text { Linda } \\
\text { Pennet }\end{array}$ & PPI/CNS (Non-voting) & Prostate cancer management & NA & $\begin{array}{l}\text { Aberdeen, } \\
\text { Scotland } \\
\text { (UK) }\end{array}$ \\
\hline $\begin{array}{l}\text { Grigoris } \\
\text { Athanasiadis }\end{array}$ & Observer & Robotic radical prostatectomy & NA & $\begin{array}{l}\text { Aberdeen, } \\
\text { Scotland } \\
\text { (UK) }\end{array}$ \\
\hline Rebecca Fish & Observer & $\begin{array}{l}\text { Colorectal surgeon and PhD } \\
\text { student developing COS in } \\
\text { anal cancer }\end{array}$ & NA & $\begin{array}{l}\text { Bristol, } \\
\text { England (UK) }\end{array}$ \\
\hline
\end{tabular}

Abbreviations: HIFU (high intensity focussed ultrasound), EBRT (electron beam radiotherapy), COS (core outcome set), HCP (healthcare professional), UCAN (urological cancer charity), PCASO (prostate cancer support organisation), LPC (localised prostate cancer), PPI (patient and public involvement) 
Table 4: Final Core Outcome Set for trials of interventions for localised prostate cancer

\begin{tabular}{|c|c|}
\hline Domain & Outcome \\
\hline \multicolumn{2}{|r|}{ Universal (i.e. applicable to all interventions) } \\
\hline Cancer/survival & Death from prostate cancer \\
\hline Cancer/survival & Death from any cause \\
\hline Cancer/survival & Local disease recurrence \\
\hline Cancer/survival & Distant disease recurrence/metastases \\
\hline Cancer/survival & Disease progression \\
\hline Cancer/survival & Need for salvage therapy \\
\hline Bowel function & Faecal incontinence \\
\hline Bowel function & $\begin{array}{l}\text { Bowel function (including diarrhoea, faecal urgency, rectal bleeding, rectal itch, } \\
\text { constipation, bowel frequency, and painful bowel movements) }\end{array}$ \\
\hline $\begin{array}{l}\text { Urinary } \\
\text { function }\end{array}$ & Stress incontinence \\
\hline $\begin{array}{l}\text { Urinary } \\
\text { function }\end{array}$ & $\begin{array}{l}\text { Urinary function (including urge incontinence, weak urine stream, nocturia, } \\
\text { haematuria, dysuria, frequency, urgency, need for temporary catheter, and } \\
\text { catheter related problems) }\end{array}$ \\
\hline Sexual function & $\begin{array}{l}\text { Sexual function (including erectile dysfunction, reduced or loss of libido, frequency } \\
\text { of intercourse, ejaculatory function, orgasmic function, and sexual function,) }\end{array}$ \\
\hline Quality of life & $\begin{array}{l}\text { Overall quality of life (including anxiety, depression, lack of confidence, feeling less } \\
\text { masculine, feeling tired or fatigued, overall quality of life, quality of life relating to } \\
\text { urinary function, quality of life relating to sexual function, quality of life relating to } \\
\text { bowel function and quality of life impact on immediate family) }\end{array}$ \\
\hline \multicolumn{2}{|r|}{ Surgery (i.e. radical prostatectomy) } \\
\hline Cancer/Survival & Positive surgical margin \\
\hline Adverse events & Perioperative deaths \\
\hline Adverse events & Thromboembolic disease \\
\hline Adverse events & Bothersome or symptomatic urethral or anastomotic stricture \\
\hline & Ablative therapy \\
\hline
\end{tabular}




\begin{tabular}{|l|l|}
\hline Cancer/survival & Treatment failure \\
\hline \multicolumn{2}{|c|}{ Active surveillance } \\
\hline Cancer/survival & Need for curative treatment \\
\hline \multicolumn{2}{|c|}{ Hormone Therapy } \\
\hline Adverse events & Side effects of hormonal therapy \\
\hline
\end{tabular}


Figure 1: Overview of core outcome set development

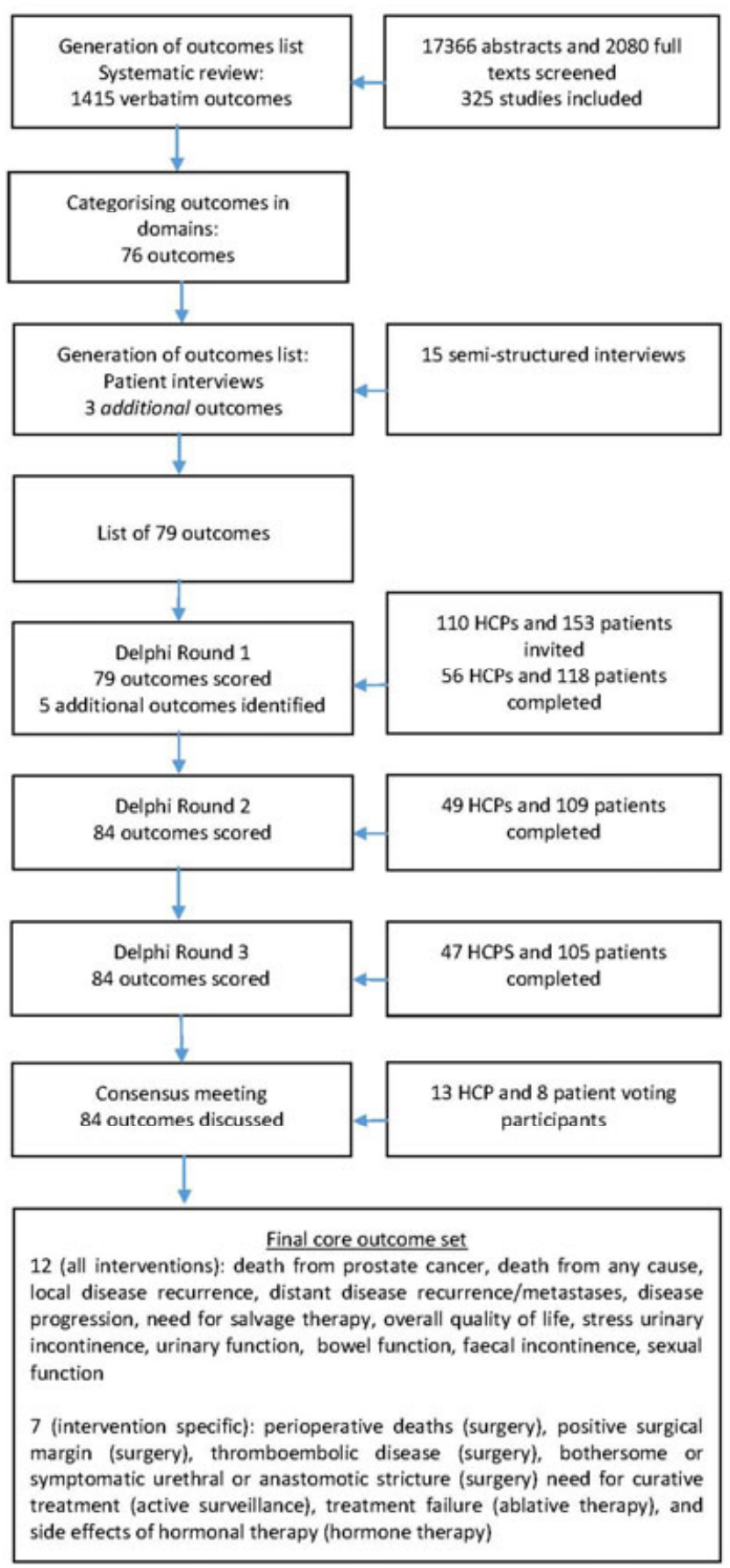


Please score the following outcomes. On each page you will see a list of outcomes organised under heading such as 'adverse events' or 'bowel function 'and you will be asked to score them on a scale of 1-9, with 1 being not important at all and 9 being critically important. We have split some of the adverse events (also known as 'side-effects') up by the type of treatments that people might have because the adverse events are not exactly the same for each treatment type. Some me might have had only surgery or radiotherapy as part of their treatment, where as some men might have had both, and other men may have had hormone treatment too. Even if you didn't have a particular treatment, you might still like to score these outcomes because they might have been important in making decisions about which treatment to have. If you feel you can't answer, just click 'unable to score'. Please specify any other important outcomes, in the space provided in the last row under 'Other' and remember to score any new outcomes you suggest.

A. Cancer-specific outcomes and survival outcomes

\begin{tabular}{|c|c|c|c|c|c|c|c|c|c|}
\hline \multirow[b]{2}{*}{ Outcome } & \multirow[b]{2}{*}{ Lay description } & \multicolumn{2}{|c|}{$\begin{array}{l}\text { Not } \\
\text { important }\end{array}$} & \multicolumn{3}{|c|}{ importamt } & \multicolumn{2}{|c|}{ Critical } & \multirow[b]{2}{*}{\begin{tabular}{|l|} 
Unable \\
to \\
score
\end{tabular}} \\
\hline & & & \begin{tabular}{l|l}
3 \\
2
\end{tabular} & 4 & 5 & 6 & & & \\
\hline \multicolumn{10}{|c|}{ Applicable to all treatments } \\
\hline 1. Desth from any cause & This cutcome refers to the death of someone from atry cause, indusing grostate cancer. & & & & & & & & \\
\hline $\begin{array}{l}\text { 2. Death from peostate } \\
\text { cancer }\end{array}$ & This outcomes refers to the death of someone as a result of prostate cancer & & & & & & & & \\
\hline $\begin{array}{l}\text { 3. Death from causes other } \\
\text { than prostate cancer }\end{array}$ & This outcome refers to the death of someone from affy causes obser than prostate cancer. & & & & & & & & \\
\hline 4. Local distase recurtence & 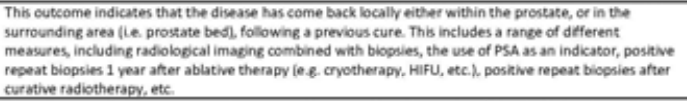 & & & & & & & & \\
\hline $\begin{array}{l}\text { 5. Distant disease } \\
\text { recurrence/metastases }\end{array}$ & $\begin{array}{l}\text { This outcoome refers to someone whose cancer has spread to other parts of their body (e.g. bones, lvmph } \\
\text { nodes, etc.). }\end{array}$ & & & & & & & & \\
\hline $\begin{array}{l}\text { 6. Disease progersion } \\
\text { (disease getting worse) }\end{array}$ & 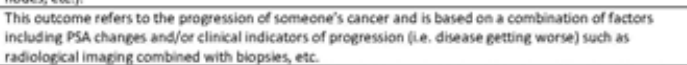 & & & & & & & & \\
\hline
\end{tabular}

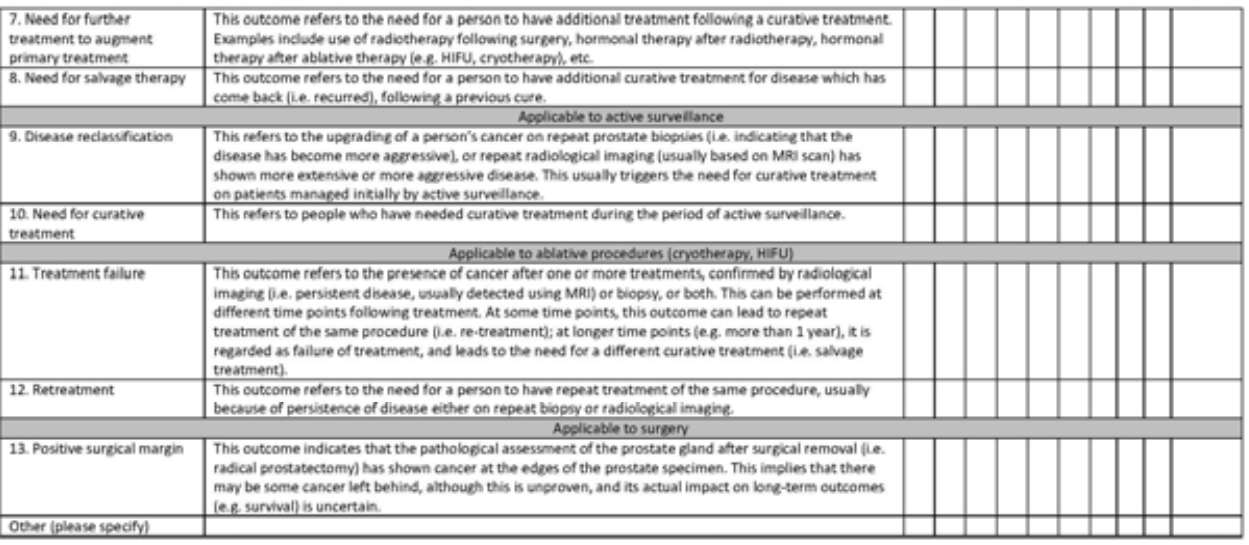

\section{B. Bowel Function}

\begin{tabular}{|c|c|c|c|c|c|c|c|c|c|c|c|}
\hline \multirow[b]{2}{*}{ Outcome } & \multirow[b]{2}{*}{ Lay description } & \multicolumn{3}{|c|}{ Not } & \multicolumn{3}{|c|}{ Important } & \multicolumn{3}{|c|}{ Cortical } & \multirow[b]{2}{*}{\begin{tabular}{|l} 
Unable \\
to seore
\end{tabular}} \\
\hline & & 1 & 2 & 3 & 4 & 5 & 6 & 7 & 8 & & \\
\hline 14. Diarrihoea & Watery stook & & & & & & & & & & \\
\hline 15. Fuecal incontisence & Uncomtroled leakage of stools & & & & & & & & & & \\
\hline 16. Faecal urpency & Having to rush to ges to the tolet to open bowels & & & & & & & & & & \\
\hline 17. Rectal bleeding & Bleeding from the back passafe & & & & & & & & & & \\
\hline
\end{tabular}




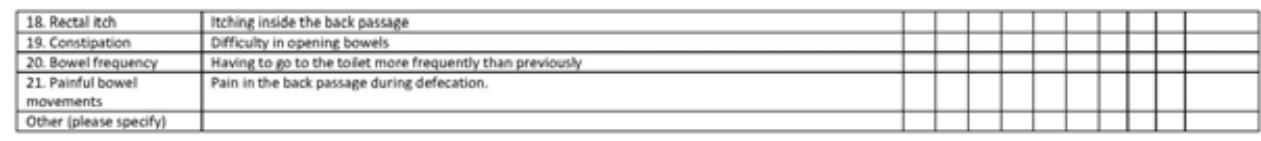

\section{c. Urinary function}

\begin{tabular}{|c|c|c|c|c|c|c|c|c|c|}
\hline \multirow[b]{2}{*}{ Outcome } & \multirow[b]{2}{*}{ Lay description } & \multicolumn{2}{|c|}{$\begin{array}{ll}\text { Not } \\
\text { important }\end{array}$} & \multicolumn{3}{|c|}{ Importam } & \multicolumn{2}{|c|}{ Gritical } & \multirow[b]{2}{*}{\begin{tabular}{|l|l} 
Unable \\
to \\
score
\end{tabular}} \\
\hline & & 12 & \begin{tabular}{l|l}
2 & 3
\end{tabular} & 4 & \begin{tabular}{|l|} 
\\
\end{tabular} & \begin{tabular}{|l|}
6 \\
\end{tabular} & & \begin{tabular}{l|l}
8 & 9
\end{tabular} & \\
\hline 22. Urge incortinense & Uncontrolled leakage of vine associated with a sensution of having to rush to pet to s tolet to vrinate & & & & & & & & \\
\hline 23. Stress incontinence & Uncontrolled leskage of vrine associated wah couphing, sneezing, running, ewerciaing, etc. & & & & & & & & \\
\hline 24. Weak urine stream & Heving a very pooc of intermittent urinary stream & & & & & & & & \\
\hline 25. Nocturia & Having to get up during the niqht to urinate & & & & & & & & \\
\hline 26. Haematuria & Vsible blood in the urine & & & & & & & & \\
\hline 27. Dysuria & Pain when urinating & & & & & & & & \\
\hline 28. Frequensy & Neesing to pass urise more frequenthy & & & & & & & & \\
\hline 28. Ureency & Feelingthe semation for having to wish to get to a tollet to urinate & & & & & & & & \\
\hline $\begin{array}{l}\text { 30. Need for a temporary } \\
\text { urethral catheter }\end{array}$ & 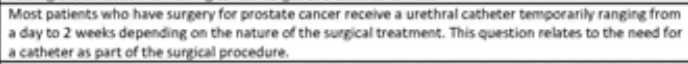 & & & & & & & & \\
\hline $\begin{array}{l}31 \text { Catheter-related } \\
\text { problems }\end{array}$ & $\begin{array}{l}\text { These refer to problems such as catheter blocking off, leaking bladder spasmb, discomfort during } \\
\text { catheter removal etc. }\end{array}$ & & & & & & & & \\
\hline Oover (please & & & & & & & & & \\
\hline
\end{tabular}

\section{Sexual Function}

\begin{tabular}{|c|c|c|c|c|c|c|c|c|c|c|c|}
\hline \multirow[b]{2}{*}{ Outcome } & \multirow[b]{2}{*}{ Lay description } & \multicolumn{3}{|c|}{$\begin{array}{l}\text { Not } \\
\text { imgortant }\end{array}$} & \multicolumn{3}{|c|}{ Important } & \multicolumn{3}{|c|}{ Critical } & \multirow[b]{2}{*}{$\begin{array}{l}\text { Unable } \\
\text { to score }\end{array}$} \\
\hline & & 1 & 2 & 3 & 4 & 5 & 6 & 7 & 8 & 9 & \\
\hline 32. Erectile dystunstion & 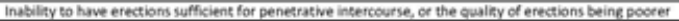 & & & & & & & & & & \\
\hline
\end{tabular}

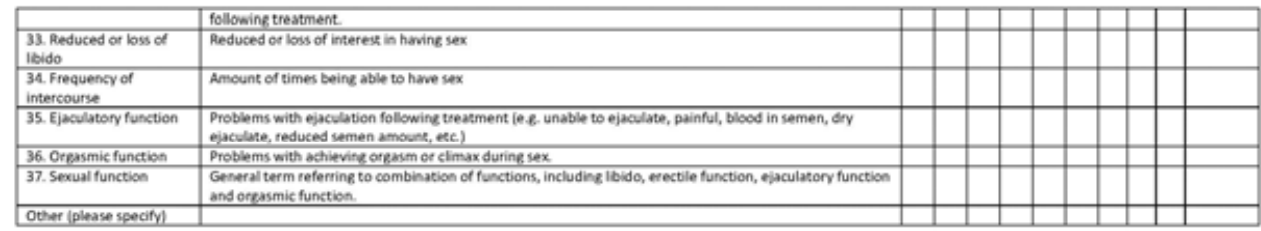

\section{E. Operation-specific and hospital-stay outcomes}

\begin{tabular}{|c|c|c|c|c|c|c|c|c|c|c|}
\hline \multirow[b]{2}{*}{ Outeome } & \multirow[b]{2}{*}{ Lay description } & \multicolumn{2}{|c|}{$\begin{array}{ll}\text { Not } \\
\text { important }\end{array}$} & \multicolumn{3}{|c|}{ Important } & \multicolumn{3}{|c|}{ Critical } & \multirow[b]{2}{*}{\begin{tabular}{|l} 
Unable \\
to \\
scare
\end{tabular}} \\
\hline & & & & & 5 & 6 & & 8 & 9 & \\
\hline \multicolumn{11}{|c|}{ Agolicable to all treatments apart from astive survelance } \\
\hline $\begin{array}{l}\text { 38. Duration of tos } \\
\text { prosedver }\end{array}$ & 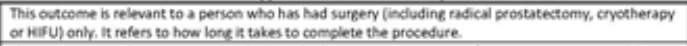 & & & & & & & & & \\
\hline 39. Pain & $\begin{array}{l}\text { This outcome is relovant to people who have had ary interventions, it refers to pain experienced during } \\
\text { and immediately atter the intervention. }\end{array}$ & & & & & & & & & \\
\hline $\begin{array}{l}\text { 40. Use of pain relief } \\
\text { medications after } \\
\text { procedsere }\end{array}$ & This ouccome refers to the amouns of mescication for pain relief patients nees after their intervention & & & & & & & & & \\
\hline 41 Catbeter duration & This outcome refers to the length of time a ureshral catheter is left in after a peocedure & & & & & & & & & \\
\hline $\begin{array}{l}\text { 42. Duration of hospital } \\
\text { stay }\end{array}$ & $\begin{array}{l}\text { This outcome is only relevant to an individwal who has a prosedure requiring them to stay in hospical it } \\
\text { refers to the length of time spent in hospital during end after the trestment. }\end{array}$ & & & & & & & & & \\
\hline 43. Time to full recovery & 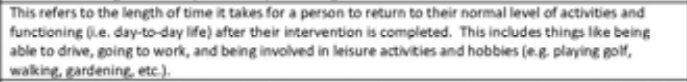 & & & & & & & & & \\
\hline $\begin{array}{l}\text { 44. Time to partial } \\
\text { recovery }\end{array}$ & 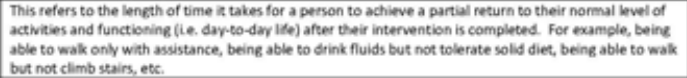 & & & & & & & & & \\
\hline
\end{tabular}




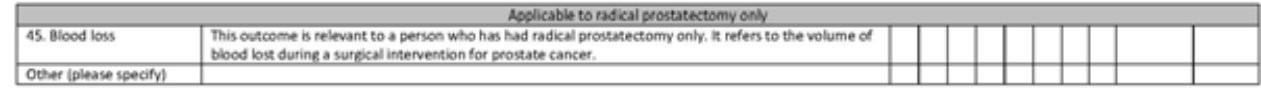

F. Quality of life and Emotional well-being

\begin{tabular}{|c|c|c|c|c|c|c|c|c|c|c|c|}
\hline \multirow[b]{2}{*}{ Outcome } & \multirow[b]{2}{*}{ Lay description } & \multicolumn{3}{|c|}{$\begin{array}{l}\text { Not } \\
\text { important }\end{array}$} & \multicolumn{3}{|c|}{ Important } & \multicolumn{3}{|c|}{ Critical } & \multirow[b]{2}{*}{$\begin{array}{l}\text { Unable } \\
\text { to scosere }\end{array}$} \\
\hline & & 1 & 2 & 3 & 4 & 5 & 6 & 7 & & 9 & \\
\hline 46. Afúcely & Feeling a mocous eather during of after treatmenc. & & & & & & & & & & \\
\hline 47. Depression & Feeling depresses eather Guring of after treatment & & & & & & & & & & \\
\hline 48. Lack el confibence & Feeding less confident about lie in peneral (es, in poing out, socialising, ecc). & & & & & & & & & & \\
\hline 49. Feeling less maxculine & Feeling less masculine as a result of treatment. & & & & & & & & & & \\
\hline $\begin{array}{l}\text { 50. Feeline tired or } \\
\text { fatipued }\end{array}$ & Feeling tires, fatieves of lethargc either during of after treatment. & & & & & & & & & & \\
\hline 51. Overal quality of life & Quality of lise in zeneral relaced to phrvical and emotional wellbeing. & & & & & & & & & & \\
\hline $\begin{array}{l}\text { 52. Qualky of ide relating } \\
\text { to urinary function }\end{array}$ & Qualty of lide specificalily related to urinary function. & & & & & & & & & & \\
\hline $\begin{array}{l}53 \text {. Qualry of life selating } \\
\text { to semual function }\end{array}$ & Quality of lise specifically related to sexual function. & & & & & & & & & & \\
\hline $\begin{array}{l}\text { 54. Quality of life relating } \\
\text { to bowel function }\end{array}$ & Qualicy of libe specificalily related to bowel function. & & & & & & & & & & \\
\hline $\begin{array}{l}\text { 55. Qualty of life impact } \\
\text { on immediate famly }\end{array}$ & Impact of treatment on immesiste family members in terms of their quality of life. & & & & & & & & & & \\
\hline Oeser (please specify) & & & & & & & & & & & \\
\hline
\end{tabular}

G. Adverse events (unwanted side effects) during and after Hormone Therapy

\begin{tabular}{|c|c|c|c|c|c|c|c|c|c|c|}
\hline \multirow[b]{2}{*}{ Outcome } & \multirow[b]{2}{*}{ Lay description } & \multicolumn{2}{|c|}{\begin{tabular}{|l|l|} 
Not \\
important
\end{tabular}} & \multicolumn{3}{|c|}{ Important } & \multicolumn{3}{|c|}{ Critical } & \multirow[b]{2}{*}{$\begin{array}{l}\text { Unable } \\
\text { to score }\end{array}$} \\
\hline & & \begin{tabular}{|l|l|}
1 & 2 \\
\end{tabular} & \begin{tabular}{l|l}
2 & 3
\end{tabular} & 4 & \begin{tabular}{|l|}
5 \\
\end{tabular} & 6 & 7 & 8 & 9 & \\
\hline 56. Hot floches & $\begin{array}{l}\text { Sudden feeling of warmness, wsually experienced most intensely over the face, neckind chest, and may } \\
\text { be associated with redness over the skin and sweating. }\end{array}$ & & & & & & & & & \\
\hline
\end{tabular}

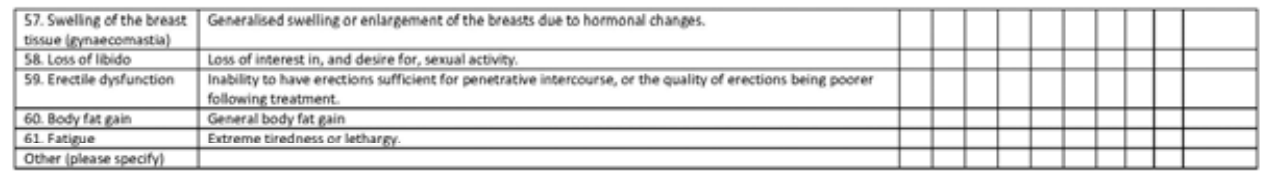

H. Adverse events (unwanted side effects) during and after radiation therapy (including External Beam Radiotherapy and Brachytherapy)

\begin{tabular}{|c|c|c|c|c|c|c|c|c|c|c|}
\hline \multirow[b]{2}{*}{ Outcome } & \multirow[b]{2}{*}{ Lay description } & \multicolumn{3}{|c|}{\begin{tabular}{|l|} 
Not \\
important
\end{tabular}} & \multicolumn{3}{|c|}{ Important } & \multicolumn{2}{|c|}{ Critical } & \multirow[b]{2}{*}{\begin{tabular}{|l|l|} 
Unable \\
to \\
score
\end{tabular}} \\
\hline & & & & & & 5 & 6 & & 39 & \\
\hline 62. Anal dikcomfort & Discomfort in the bak passape. & & & & & & & & & \\
\hline 63. Ureethral stricture & Blockape to the water passape within the penis due to formation of scar tissue & & & & & & & & & \\
\hline 64. Radiation procttis & Inflammation of the rectum caused by radiocherapy & & & & & & & & & \\
\hline $\begin{array}{l}\text { 65. Acute urinary } \\
\text { restention }\end{array}$ & Inability to pass water, sometimes resulting in painful swelling of the bladser. & & & & & & & & & \\
\hline 66. Fatioue & Feeling tired of lethargis. & & & & & & & & & \\
\hline 67. Haensuturia & Passing blood mixed wich Uine. & & & & & & & & & \\
\hline Other (please specify) & & & & & & & & & & \\
\hline
\end{tabular}

L. Adverse events for surgery (including open, laparoscopic and robotic surgery, cryotherapy and HIFU

\begin{tabular}{|c|c|c|c|c|c|c|c|c|c|c|c|}
\hline \multirow[b]{2}{*}{ Outcome } & \multirow[b]{2}{*}{ Lay description } & \multicolumn{3}{|c|}{\begin{tabular}{|l|} 
Not \\
important \\
\end{tabular}} & \multicolumn{3}{|c|}{ Important } & \multicolumn{3}{|c|}{ Critikal } & \multirow[b]{2}{*}{$\begin{array}{l}\text { Unable } \\
\text { to score }\end{array}$} \\
\hline & & 1 & 2 & 3 & 4 & 5 & 6 & & 8 & 9 & \\
\hline $\begin{array}{l}\text { 68. Acarte of sub-acute } \\
\text { bowel obstrustion }\end{array}$ & Sudden blockage to the gut doe to formubion of scar tisue within the gut or surrounding saeas. & & & & & & & & & & \\
\hline $\begin{array}{l}\text { 69. Acute urinary } \\
\text { resemsion }\end{array}$ & Inability to pass water resulting in painful swelling of the bladder. & & & & & & & & & & \\
\hline 70. Anastomotic leak & Lestage of urine as a result of the joimt between the bladder and wher pipe not being watertiotht. & & & & & & & & & & \\
\hline
\end{tabular}




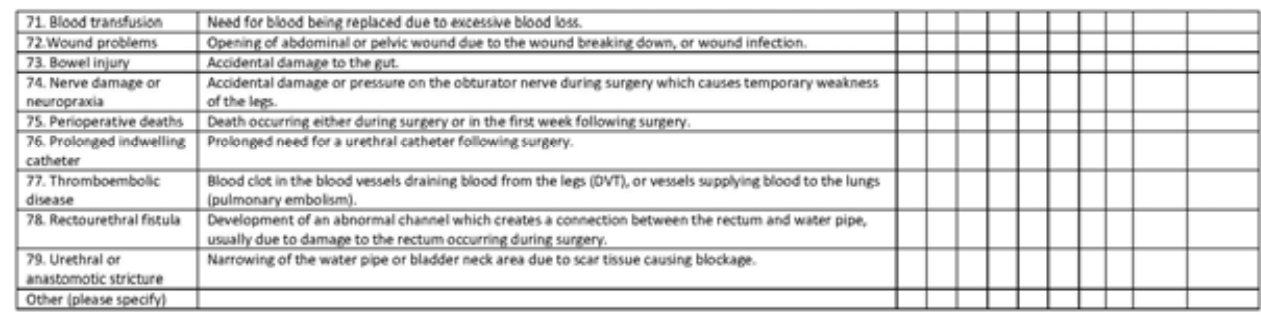

Appendix 2: Detailed Characteristics of HCPs completing all 3 Delphi survey rounds

\begin{tabular}{|l|l|l|}
\hline Name & City, country of residence & Expertise \\
\hline Alan Mcneill & Edinburgh, Scotland (UK) & Surgery (lap) \\
\hline Alasdair Innes & Edinburgh, Scotland (UK) & Urology CNS \\
\hline Alessandro Volpe & Novara, Italy & Surgery (robotic) \\
\hline Axel Bex & Amsterdam, The Netherlands & Surgery \\
\hline Axel Merseburger & Hannover, Germany & Oncology (medical) \\
\hline Balazs Binnyei & Aberdeen, Scotland (UK) & Surgery \\
\hline Borje Ljungberg & Umea, Sweden & Urology CNS \\
\hline Brian Corr & Inverness, Scotland (UK) & Oncology CNS \\
\hline Danny Lynch & Aberdeen, Scotland (UK) & Surgery (lap/robotic) \\
\hline David Douglas & Inverness, Scotland (UK) & \\
\hline
\end{tabular}




\begin{tabular}{|c|c|c|}
\hline Debbie Munro & Aberdeen, Scotland (UK) & Urology CNS \\
\hline Duncan McLaren & Newcastle, England (UK) & Oncology (clinical) \\
\hline Eric Borg & Aberdeen, Scotland (UK) & Urology CNS \\
\hline Graham Macdonald & Aberdeen, Scotland (UK) & Oncology (clinical) \\
\hline Grant Stewart & Edinburgh, Scotland (UK) & Surgery (lap) \\
\hline Hashim Ahmed & London, England (UK) & Surgery (HIFU) \\
\hline Henk Van der Poel & Amsterdam, The Netherlands & Surgery (robotic) \\
\hline Hugh Mostafid & Basingstoke, England (UK) & Surgery (lap) \\
\hline Ian Pearce & Manchester, England (UK) & Surgery (lap) \\
\hline James N'Dow & Aberdeen, Scotland (UK) & Surgery \\
\hline Jim Catto & Sheffield, England (UK) & Surgery (robotic) \\
\hline Judith Grant & Aberdeen, Scotland (UK) & Oncology (clinical) \\
\hline Justine Royle & Aberdeen, Scotland (UK) & Surgery (lap/robotic) \\
\hline Kevin Wardlaw & Aberdeen, Scotland (UK) & Urology CNS \\
\hline Lesley Simpson & Aberdeen, Scotland (UK) & Urology CNS \\
\hline Linda Pennet & Aberdeen, Scotland (UK) & Urology CNS \\
\hline Malcolm Mason & Cardiff, Wales (UK) & Oncology (clinical) \\
\hline Nicholas Cohen & Aberdeen, Scotland (UK) & Surgery \\
\hline Nicolas Mottet & St. Etienne, France & Surgery (lap) \\
\hline Pam Barker & Aberdeen, Scotland (UK) & Surgery \\
\hline Paul Abel & London, England (UK) & Surgery \\
\hline Paul Halliday & Dundee, Scotland (UK) & Surgery \\
\hline Peter Cooke & Wolverhampton, England (UK) & Surgery \\
\hline Philip Cornford & Liverpool, England (UK) & Surgery (robotic) \\
\hline Philipp Dahm & Minneapolis, USA & Surgery \\
\hline
\end{tabular}




\begin{tabular}{|l|l|l|}
\hline Robert Jones & Glasgow, Scotland (UK) & \\
\hline Robert Mills & Norwich, England (UK) & Oncology (medical) \\
\hline Roger Kocklebergh & Leicester, England (UK) & Surgery \\
\hline Sam McClinton & Aberdeen, Scotland (UK) & Surgery \\
\hline Satchi Swami & Aberdeen, Scotland (UK) & Surgery \\
\hline Steve Leung & Dunfermline, Scotland (UK) & Surgery \\
\hline Steven Canfield & Houston, USA & Surgery (robotic) \\
\hline Thomas Lam & Aberdeen, Scotland (UK) & Surgery (lap/robotic) \\
\hline Thomas Wiegel & Ulm, Germany & Oncology (clinical) \\
\hline William Cross & Leeds, England (UK) & Surgery (robotic) \\
\hline
\end{tabular}


Appendix 3: Results of voting for all outcomes voted on during consensus group meeting

\begin{tabular}{|c|c|c|c|}
\hline Outcome (applicable interventions) & $\begin{array}{l}\text { Not } \\
\text { important }\end{array}$ & Important & Critical \\
\hline \multicolumn{4}{|c|}{ A.CANCER SPECIFIC AND SURVIVAL OUTCOMES } \\
\hline 1. Death from any cause (universal) & $5 \%$ & $0 \%$ & $95 \%$ \\
\hline 2. Death from prostate cancer (universal) & $0 \%$ & $5 \%$ & $95 \%$ \\
\hline 3. Death from causes other than prostate cancer (universal) ++ & $5 \%$ & $0 \%$ & $95 \%$ \\
\hline 4. Local disease recurrence (universal) & $0 \%$ & $19 \%$ & $81 \%$ \\
\hline 5. Distant disease recurrence/metastases (universal) & $0 \%$ & $5 \%$ & $95 \%$ \\
\hline 6. Disease progression (universal) & $0 \%$ & $5 \%$ & $95 \%$ \\
\hline $\begin{array}{l}\text { 7. Need for further treatment to augment primary treatment } \\
\text { (universal) }\end{array}$ & $14 \%$ & $57 \%$ & $29 \%$ \\
\hline 8. Need for salvage therapy (universal) & $0 \%$ & $10 \%$ & $91 \%$ \\
\hline 9. Disease reclassification (Active surveillance) & $0 \%$ & $33 \%$ & $67 \%$ \\
\hline 10. Need for curative treatment (Active surveillance) & $0 \%$ & $14 \%$ & $86 \%$ \\
\hline 11. Treatment failure (Ablative) & $0 \%$ & $5 \%$ & $95 \%$ \\
\hline 12. Retreatment (Ablative) & $10 \%$ & $29 \%$ & $62 \%$ \\
\hline 13. Positive surgical margin (Surgery) & $0 \%$ & $24 \%$ & $76 \%$ \\
\hline \multicolumn{4}{|l|}{ B. BOWEL FUNCTION } \\
\hline 14. Bowel function (universal)* & $0 \%$ & $20 \%$ & $80 \%$ \\
\hline 15. Faecal incontinence (universal) & $0 \%$ & $14 \%$ & $86 \%$ \\
\hline \multicolumn{4}{|l|}{ C. URINARY FUNCTION } \\
\hline 23. Stress incontinence (universal) & $14 \%$ & $14 \%$ & $71 \%$ \\
\hline 24. Urinary Function (universal)* & $0 \%$ & $5 \%$ & $95 \%$ \\
\hline 26. Haematuria (universal) & $15 \%$ & $70 \%$ & $15 \%$ \\
\hline 30. Need for temporary catheter (universal) & $40 \%$ & $60 \%$ & $0 \%$ \\
\hline 31. Catheter-related problems (urinary function) & $30 \%$ & $60 \%$ & $10 \%$ \\
\hline \multicolumn{4}{|l|}{ D. SEXUAL FUNCTION } \\
\hline 37. Sexual Function (universal)* & $0 \%$ & $10 \%$ & $85 \%$ \\
\hline \multicolumn{4}{|c|}{ E. OPERATION SPECIFIC AND HOSPITAL-STAY OUTCOMES } \\
\hline \multicolumn{4}{|l|}{ Applicable to all treatments apart from Active surveillance } \\
\hline 43. Time to full recovery (universal) & $14 \%$ & $67 \%$ & $19 \%$ \\
\hline \multicolumn{4}{|c|}{ F. QUALITY OF LIFE AND EMOTIONAL WELL-BEING } \\
\hline 51. Overall Quality of Life (universal) & $5 \%$ & $10 \%$ & $86 \%$ \\
\hline 52. Quality of life relating to urinary function (universal) & $100 \%$ & $0 \%$ & $0 \%$ \\
\hline 54. Quality of life relating to bowel function (universal) & $95 \%$ & $5 \%$ & $0 \%$ \\
\hline \multicolumn{4}{|c|}{ H. ADVERSE EVENTS DURING AND AFTER RADIATION THERAPY } \\
\hline 63. Bothersome or symptomatic Urethral stricture & $0 \%$ & $24 \%$ & $76 \%$ \\
\hline
\end{tabular}




\begin{tabular}{|c|c|c|c|}
\hline 65. Acute urinary retention (all interventions) & $10 \%$ & $48 \%$ & $43 \%$ \\
\hline 66. Fatigue (all interventions) (REWORDED) & $0 \%$ & $35 \%$ & $65 \%$ \\
\hline 68. Acute or sub-acute bowel obstruction (AE surgery) & $0 \%$ & $38 \%$ & $62 \%$ \\
\hline 69. Acute urinary retentionall treatments & $100 \%$ & $0 \%$ & $0 \%$ \\
\hline \multicolumn{4}{|c|}{ I. ADVERSE EVENTS DURING AND AFTER SURGERY } \\
\hline 70. Anastomotic leak & $5 \%$ & $76 \%$ & $19 \%$ \\
\hline 72. Wound problems & $29 \%$ & $62 \%$ & $10 \%$ \\
\hline 74. Nerve damage or neuropraxia & $38 \%$ & $24 \%$ & $0 \%$ \\
\hline 75. Perioperative deaths & $5 \%$ & $5 \%$ & $91 \%$ \\
\hline 77. Thromboembolic disease & $0 \%$ & $29 \%$ & $71 \%$ \\
\hline 79. Bothersome or symptomatic urethral or anastomotic stricture & $0 \%$ & $33 \%$ & $67 \%$ \\
\hline \multicolumn{4}{|c|}{ Additional outcomes suggested by participants in Round 1 of Delphi } \\
\hline 80. Impact on relationship with partner & $0 \%$ & $80 \%$ & $20 \%$ \\
\hline 83. Induction of new cancers $\S$ & $10 \%$ & $24 \%$ & $76 \%$ \\
\hline 84. Side effects of hormonal therapy & $0 \%$ & $5 \%$ & $95 \%$ \\
\hline 85. 'Bowel injury' and 'rectourethral fistula' considered together* & $5 \%$ & $47 \%$ & $47 \%$ \\
\hline
\end{tabular}

Key: Green cells indicate outcomes meeting consensus 'in'. Red cells indicate $\geq 70 \%$ critical

++ Although initially voted 'in', 'death from causes other than prostate cancer' was subsequently discussed and voted out because it is structurally related to 'death from any cause' and 'death from prostate cancer'.

$\S$ Although initially voted 'in', 'Induction of new cancers' was subsequently discussed and voted out because it was considered to be very rare and late occurring and therefore unlikely to be feasible to collect in effectiveness trials.

* Outcomes re-categorised during consensus meeting

'Bowel function' includes: diarrhoea, faecal urgency, rectal bleeding, rectal itch, constipation, bowel frequency, and painful bowel movements

'Urinary function' includes: urge incontinence, weak urine stream, nocturia, haematuria, dysuria, frequency, urgency, need for temporary catheter, and catheter related problems

'Sexual function' includes: erectile dysfunction, reduced or loss of libido, frequency of intercourse, ejaculatory function, orgasmic function, and sexual function

'Overall quality of life' includes: anxiety, depression, lack of confidence, feeling less masculine, feeling tired or fatigued, overall quality of life, quality of life relating to urinary function, quality of life relating to sexual function, quality of life relating to bowel function and quality of life impact on immediate family 